\title{
Communication/Comunicação
}

\section{Humoral immune response of patients bitten by the snake Bothrops erythromelas}

\author{
Resposta imune humoral em pacientes picados pela serpente Bothrops erythromelas
}

\section{Karla Patricia Oliveira Luna ${ }^{1,2}$, Edeneide Maria Xavier ${ }^{2}$, Vanessa Peruhype Magalhães Pascoal ${ }^{3}$, Olindo Assis Martins-Filho ${ }^{3}$ and Valéria Rêgo Alves Pereira ${ }^{2}$}

\begin{abstract}
Introduction: Snake envenomings are a health problem in rural areas of tropical and subtropical countries, but little is known regarding the immune response presented by bitten individuals. The IgM production of patients bitten by Bothrops erythromelas snake was analyzed to identify the effectiveness of treatment in this type of envenomation. Methods: Bothrops erythromelas venom was submitted to electrophoresis and transferred to a nitrocellulose sheet, following incubation with patients' sera. Results: A 38 KDa protein was detected before and $24 \mathrm{~h}$ after therapy. Conclusions: The result suggests that this protein could be used as a marker for individuals envenomed by Bothrops. erythromelas.
\end{abstract}

Key-words: Snake venom. Western blotting. IgM. Bothrops erythromelas.

\section{RESUMO}

Introdução: Envenenamentos ofídicos consistem problema de saúde pública em áreas rurais de países tropicais e subtropicais, mas pouco sabe-se sobre a resposta imune apresentada pelos indivíduos picados, por isso a avaliação da produção de $\operatorname{IgM}$ por pacientes picados por Bothrops erythromelas identificando a eficácia do tratamento nesse tipo de envenenamento. Métodos: O veneno de Bothrops erythromelas foi submetido a eletroforese e transferido para nitrocelulose, seguindo incubação com soro de pacientes. Resultados: Foi observada proteína de $38 \mathrm{KDa}$ antes e 24 horas após o tratamento. Conclusões: Os resultados sugerem que essa proteína poderia ser utilizada como marcador para indivíduos envenenados pela serpente Bothrops erythromelas.

Palavras-chaves: Veneno ofídico. Western blotting. IgM. Bothrops erythromelas.

Snakebites occur worldwilde and are a public health problem, victimizing around 421,000 people every year and involving 20,000 deaths ${ }^{1}$. The Bothrops genus is responsible for $90.6 \%$ of the reported envenomings ${ }^{2}$. In Northeastern Brazil, the endemic species is Bothrops erythromelas, locally known as jararaca-da-seca. Bothrops venoms induce local and systemic hemorrhaging, coagulopathy, edema, local necrosis and can lead to death and/or permanent disabilities ${ }^{3-5}$. Since little is known regarding the isotype and specificity of antibodies produced by patients bitten by the Botrhops erythromelas snake, this

1. Departament of Biology, Center of Biological and Health Sciences, State University of Paraíba, Campina Grande, PB, Brazil. 2. Departament of Immunology, Research Center Aggeu Magalhães, Fundação Oswaldo Cruz, Recife, PE, Brazil. 3. Laboratory of Biomarkers and Monitoring, Departament Research Center René Rachou, Belo Horizonte, MG, Brazil.

Address to: Dra. Karla P. Oliveira Luna. Dept ${ }^{\circ}$ de Imunologia/Centro de Pesquisas Aggeu Magalhães. Avenida Moraes Rego S/N, Cidade Universitária, 50.670-420 Recife, PE, Brasil.

Phone: 5581 2101-2631

e-mail: karlaceatox@yahoo.com.br

Received in 23/03/2010

Accepted in 12/05/2010 paper describes the immune response in three groups of patients bitten by this snake in the City of Campina Grande, Paraíba State, Brazil.

Serum samples before treatment, 12 and $24 \mathrm{~h}$ posttreatment were collected from patients bitten by the snake Bothrops erythromelas. At the hospital, these patients were separated into three groups, according to the severity of envenomation: mild $^{4}$, moderate ${ }^{4}$ and severe ${ }^{3}$. All patients were submitted to serum therapy at the same hospital. Those who agreed to participate in this study signed a term of free, informed consent. This study was approved by the Ethics Comitee of the Universidade Estadual da Paraíba (UEPB). Blood was collected immediately after patient admittance to the hospital. Serum was collected, centrifuged and stored at $-20^{\circ} \mathrm{C}$ till the moment of analysis. Antigens of Bothrops erythromelas venom that react with patient antibodies were analyzed by western blotting, following Towbin et $\mathrm{al}^{6}$.

To determine whether patient antibodies reacted to venom antigens showing an IgM production pattern, pools of serum from all the patients collected before treatment were analyzed. In all patients, whether classified as mild, moderate or severe envenomation, the main $38 \mathrm{KDa}$ protein was detected.

To evaluate the pattern of antibodies recognizing $\operatorname{IgM}$ after $24 \mathrm{~h}$ of treatment, all patients were again analyzed and the same protein was detected (Figure 1).

It should be emphasized that despite serum therapy, the antibody response to Bothrops erythromelas followed a humoral immune response which is classic for many diseases: primary IgM production. This IgM production was previously observed using Bothrops jararaca venom with patients bitten by this snake ${ }^{7}$.

In this work, the main $38 \mathrm{KDa}$ protein was observed before and $24 \mathrm{~h}$ after therapy. It is important to highlight that this could serve as a marker for Bothrops erythormelas envenomation, since this protein is not well neutralized by the commercial antivenom used in Brazil, perhaps because the antivenom pool does not include the Bothrops erythromelas species. The pool of antivenom used in Brazil may have a low efficacy for B. erythromelas venom neutralization.

In another study, the authors had previously observed that Bothrops jararaca venom is not well neutralized by the commercial antivenom, since patients analysed showed different patterns of recognition, which could implicate the genetic background of each patient or the degree of absorption of venom components ${ }^{7}$. In this study, the authors elucidated a clearer understand regarding the humoral immune response elicited by patients bitten by Bothrops erythromelas as a way of developing a potential new therapy approach. 


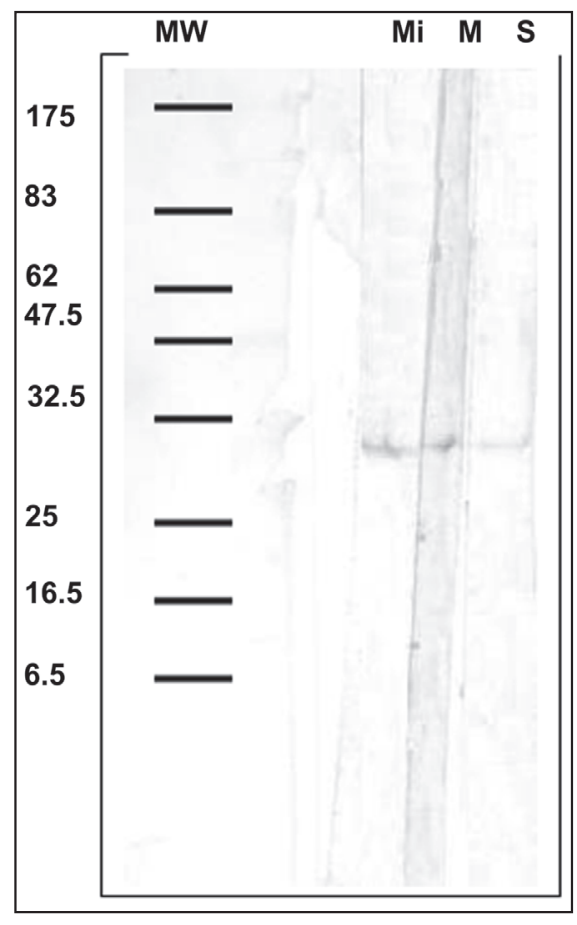

FIGURE 1 - Immunoblotting showing the reaction of Bothrops erythromelas venom and serum of patients after 24hours treatment; $25 \mu \mathrm{g}$ of Bothrops erythromelas venom diluted 1:100 were electrophorased on 10\% SDS-PAGE under non reducing conditions and transferred to a nitrocellulose paper, blocked with $5 \%$ milk containing $0,05 \%$ Tween 20 and incubated with patients serum under $4^{\circ} \mathrm{C}$ overnight. Estimated molecular markers are shown.

MW: molecular weight, Mi: mild, M: moderate, S: strong envenomation.

\section{ACKNOWLEDGMENTS}

The authors would like to thank CEATOX-Campina Grande, PB, where patients were selected and Répteis da Caatinga, from where venom was purchased.

\section{CONFLICT OF INTEREST}

The authors declare that there is no conflict of interest.

FINANCIAL SUPPORT

Fundação Oswaldo Cruz - FIOCRUZ.

\section{REFERÊNCIAS}

1. Kasturiratne A, Wickremasinghe AR, de Silva N, Gunawardena NK, Pathmeswaran A, Premaratna R, et al. The global burden of snakebite: a literature analysis and modeling based on regional estimates of envenoming and deaths. PLoS Medicine 2008; 11:e218.

2. Brasil. Ministério da Saúde. Acidentes ofídicos: contribuição ao estudo da morbidade; 1990.

3. Markland FS. Snake venoms and the hemostatic system. Toxicon 1998; 36:1749-1800.

4. Bjarnason JB, Fox JW. Hemorragic metalloproteinases from snake venoms. Pharmacol Ther 1994; 62:325-372

5. Gutiérrez JM, Lomonte B. Local tissue damage induced by Bothrops snake venoms. A review. Mem Inst Butantan 1989; 51:211-223.

6. Towbin H, Staehelin T, Gordon J. Electrophoretic transfer of proteins from polyacrylamide gels to nitrocellulose sheets: procedure and some applications. Proc Natl Acad Sci USA 1979; 76:4350-4354.

7. Domingos MO, Cardoso JL, Moura-da-Silva AM, Mota I. The humoral immune response of patients bitten by the snake Botrhops jararaca (jararaca). Toxicon 1990; 28:723-726. 